\title{
Markets and Morality: Complements or Substitutes?
}

\author{
MARIA PIA PAGANELLI \\ Trinity University
}

Virgil Storr and Ginny Choi (2019) ask if markets corrupt our morals. This is a question dear to me as much of my work on Adam Smith addresses versions of this question (Paganelli 2008, 2009, 2010, 2017b; Al-Ubaydli et al. 2013).

Storr and Choi's answer is a resounding no: markets do not corrupt our morals. To the contrary, markets have a symbiotic relationship with morality. Markets need morality to survive and thrive, and at the same time, markets make us more moral. The authors support this claim with empirical and theoretical evidence. Despite my affinity to their positions, and my agreement that markets need morality to function, given my work on Adam Smith, I fear they may have posed the question in a misleading way. This may compromise their answer. They ask: do markets corrupt our morals? But to whom do they refer? Whose is 'our' in this inquiry? Twenty-first-century intellectuals of western countries? All of humanity? Could 'our' apply to medieval monks? Or to Spartan warriors?

Claims such as "markets make us better people" (194) or "on average, people who live in market societies exhibit more virtue and less vice than people who live in nonmarket societies" (234) are present throughout the book. But, what if we consider the converse of these claims? For example, that 'nonmarket (societies) make us worse people', or that 'on average, people who live in nonmarket societies exhibit more vice and less virtue than people who live in market societies'. Do Storr and Choi really want to claim that people in, say, Italy, Spain, Costa Rica, Guatemala, Kenya, or Mozambique, i.e. countries which qualify as nonmarket societies, are on average less moral than people in the United States or the Bahamas, countries which qualify as market societies? And, assuming that such claims are not limited to contemporary society, could we say that, on average, medieval monks are immoral? What about Spartan warriors? Or Native Americans at the time of Columbus? 
I fear the way Storr and Choi present their argument might imply the claim that I (or, on average, someone), by living in North America today, am a more virtuous and more moral person than a refugee from Syria (on average). If this is the claim they are indeed making, I strongly and categorically distance myself from their perspective. If, on the other hand, they are trying to respond to accusations that markets corrupt us, then I think they could have posed the question in a different way. Adam Smith may help us to understand this distinction. And in this, I will offer a different reading of Smith than Storr and Choi offer.

In my reading of Adam Smith, yes, markets do corrupt our morals, and no, markets do not corrupt our morals: markets make us more vicious and markets also make us more virtuous. The problem lies in the interpretation of who constitutes 'our'. Markets do corrupt a set of morals present in non-commercial societies. But markets replace those morals with a different set of morals. So, it is not that markets crowd out virtues, leaving a vacuum, but that markets substitute a set of virtues with another set of different virtues. In this sense, markets both corrupt morals and help us become moral. Both statements are correct, because 'our morals' may not be a fixed set of morals, but different sets of morals.

In my understanding of Adam Smith, he presents us with a theory of endogenous preference formation, which translates into a theory of endogenous virtues/vices formation (Paganelli 2018). Given the constancy of human nature, we behave differently given different constraints; and the constraints we face will determine what is appropriate and what is not appropriate, what deserves approbation and what deserve disapprobation. Different constraints will thus generate the appropriate set of virtues and/or moral behaviors, and they will vary with the variations of the constraints.

Smith is explicit in both The Theory of Moral Sentiments and Wealth of Nations that different systems of morals are appropriate in different circumstances. ${ }^{1}$ In my reading of Smith, he does not suggest that there is a univocal set of virtues, but argues that what is considered a virtuous

\footnotetext{
${ }^{1}$ This and all subsequent references to The Theory of Moral Sentiments, abbreviated as ' $T M S$ ', are to the Glasgow edition (Smith [1759] 1981a). References include, in this order, part (in upper case Roman numerals), section (where applicable, in lower case Roman numerals), chapter, and paragraph (in Arabic numerals). Similarly, references to the Wealth of Nations, abbreviated as ' $W N$ ', are also to the Glasgow edition (Smith [1776] 1981b). References include, in this order, book (in upper case Roman numerals), chapter (in lower case Roman numerals), part (where applicable, in lower case Roman letters), and paragraph (in Arabic numerals).
} 
behavior depends on circumstances (Bee and Paganelli 2019; Paganelli 2017a).

In TMS, he tells us that if a military general starts crying uncontrollably in front of all his soldiers when he receives the news of the death of his child, he would not be considered virtuous. He should keep a stiff upper lip when in command. But once home, if he keeps a straight face and expresses indifference to the news in the intimacy of his family, he would be considered a monster and not a virtuous person (TMS, V.2.5). Virtue is circumstantial.

Smith continues (TMS, III.3.37), under a "boisterous and stormy sky", we value the virtue of self-command. In a boisterous storm, we suppress the expression of our emotions. Openly panicking or showing how much we suffer will not do any good. To the contrary, it will jeopardize our lives and the lives of the people around us. We are better off suppressing the expression of our emotions. Our lack of expression of emotions, which for Smith is the essence of self-command, is valued in situations in which life, and the lives of those around us, is in constant danger. War is thus the best school for self-command. Hunter-gatherers, who also face constant threats of death, value self-command as the most important virtue. But complete self-command, which for Smith implies a lack of expression of emotions, is not something we value in the "mild sunshine" (TMS, III.3.37). In a boisterous storm, yes; in mild sunshine, no. In mild sunshine, when we live in comfort, when we do not have to worry constantly about our survival, then the 'masculine' virtue of self-command is replaced with the 'feminine' virtue of humanity (on masculine and feminine virtues in Smith see, for example, Montes 2004; and Sebastiani 2013). Humanity is the opposite of self-command. It is the (appropriate) expression of emotions that generates the joy of mutual sympathy. Humanity on the battlefield is not a virtue. It is a dangerous thing and it should be avoided. Selfcommand is the appropriate virtue to display there. But the same virtuous self-command on a battlefield becomes a monstrous thing in the warm intimacy of friends and family. Humanity substitutes self-command given the different set of constraints (see also TMS, V.2.8; and Bee and Paganelli 2019; cf. Carrasco 2012).

Similarly, Smith explicitly claims in the Wealth of Nations (V.i.g.10) that we have two systems of morality, which run parallel to one another. One is not better than the other; rather, one is more appropriate than the other given the circumstances. For Smith, there is an "austere system" of morality adopted by and appropriate for the poor, and a "loose system" 
of morality adopted by and appropriate for the rich ( $W N$, V.i.g.10). The rich, being rich, can afford luxuries and extravagances. A life of excesses will have little impact on their wealth. A loose system of morality is thus appropriate for them. The poor would ruin themselves and their families quickly if they engaged in the same behavior. So, an austere system of morality is what is appropriate and virtuous for them.

Differently from Deirdre McCloskey (2006), who, as cited in Storr and Choi, claims that the increase in wealth in the West was caused by a change in attitude toward merchants (without telling us what caused that change in attitude), Smith claims that this change in attitude came from a change in constraints. The accumulation of capital caused profit rates to decrease. Holland accumulated so much capital, in Smith's account, that living on the returns of it became impossible. People needed to work, to be actively involved in commercial activities to make a living. And since so many had to do it, it became fashionable ( $W N$, I.ix.20). Here again, it is the change in constraints that originally caused the change in attitude and the change in what was deemed worthy of approbation.

The examples of different sets of virtues being appropriate under different circumstances abound in Smith. And this is why I am reluctant to answer Storr and Choi's question in the same way they have done. They read Smith as supporting markets for their material betterment but criticizing markets for their potential corruption of our morals. For example, for them, markets corrupted the "poor man's son" (TMS, IV.1.8), who, cursed with ambition, worked all his life to accumulate wealth and then, sick and old, realized that wealth did not give him the happiness he hoped for. Yet, his delusions made us all better off as his work improved society. Distancing themselves from Smith, Storr and Choi claim that markets do not need to corrupt our morals, but rather, that they improve our morals.

First, I am not sure the morals of the poor man's son were corrupted. He did nothing wrong-he did not elbow anybody aside or cheat his competitors (TMS, II.ii.2.1). He did not steal and did not hurt anyone. He may (or may not) have been wrong about what brings happiness, but that does not make him immoral or vicious. Merchants and manufacturers, on the other hand, when they collude to keep the wage of workers low, or when they successfully lobby to obtain privileges that enrich themselves with the "blood and treasure" (WN, IV.vii.c.63) of others, have corrupted morals. Is that corruption caused by the market? Maybe. But the corruption happens only when the market is pushed into the hands of the privilege- 
granting power of the state. That is where morals are unquestionably compromised, not when one works in an honest way.

For Smith, markets do corrupt our morals, if our morals are the morals of a feudal system. Markets make us undisciplined and cowardly in war, weaken hospitality, feed our vanity, and challenge austerity. But they do not create moral monsters unless we are able to access the monopoly power of the state. Markets substitute the more typical masculine virtues of pre-commercial societies with the more feminine virtues of commercial society. We may weep like babies over a small fine (a corruption of morality from the pre-commercial/masculine perspective), but we offer the comfort of a shoulder to cry on to our friends (a moral act from the feminine/commercial perspective). Those living in a commercial society tend to be more cowardly in wars but tend to be more punctual in the fulfillment of their contracts (Paganelli forthcoming). Hence, markets create different constraints. What is appropriate and worthy of approbation will vary from constraint to constraint.

In Smith's account, asking for women's independence in a huntergathering society is close to impossible. It is virtuous for a woman to stay 'home' and let the hunting to the physically stronger man. An independent woman would be a dead woman in that society. But in a society where bread is earned not by physical strength but through manufacturing or some other form of non-physical skills, family values are not as important since a woman can earn her living on her own. Women's emancipation becomes feasible and virtuous. So, in a sense it is true that markets destroy the family; but they replace one set of values with a different one, more appropriate to the new circumstances. For example, cosmopolitanism is a virtue only when a stranger does not kill you. In hunter-gatherer or pastoral societies, when strangers come to kill you and steal the little you have, welcoming them is not a virtue, it is reckless. The virtue in that context is to defend yourself and your possessions, to fight strangers and torture them to death so that their clan members will not try to do the same. Torturing a stranger in the twenty-first-century western world is abhorrent. Welcoming a stranger in a hunter-gather society, in a Smithian framework, is similarly abhorrent (on different institutions in different stages of development in Smith, see, among others, Berry 1997; Smith 2006). The constraints are different, so the system of morals is also different.

In response to Storr and Choi, I would rather say: markets do corrupt our morals and replace them with a different set of morals that are more 
appropriate to the new constraints that markets create. Markets are indeed doux, not because they make better people or more virtuous people, but because they soften our spirit, substituting one set of virtues with another. One is not better than the other-one is more appropriate to the specific circumstances than the other.

That said, the book is pleasantly written and worth reading. The topic is both actual and it engages centuries long debates. It will offer the reader many excellent foods for thought.

\section{REFERENCES}

Al-Ubaydli, Omar, Daniel Houser, John Nye, Maria Pia Paganelli, and Xiaofei Sophia Pan. 2013. "The Causal Effect of Market Priming on Trust: An Experimental Investigation Using Randomized Control.” PLoS ONE 8 (3): e55968.

Bee, Michele, and Maria Pia Paganelli. 2019. "Adam Smith, Anti-Stoic.” History of European Ideas 45 (4): 572-584.

Berry, Christopher J. 1997. Social Theory of the Scottish Enlightenment. Edinburgh: Edinburgh University Press.

Carrasco, Maria A. 2012. "Adam Smith: Self-Command, Practical Reason and Deontological Insights." British Journal for the History of Philosophy 20 (2): 391-414.

McCloskey, Deirdre. 2006. The Bourgeois Virtues: Ethics for an Age of Commerce. Chicago, IL: University of Chicago Press.

Montes, Leonidas. 2004. Adam Smith in Context: A Critical Reassessment of Some Central Components of his Thought. New York, NY: Palgrave Macmillan.

Paganelli, Maria Pia. 2008. "The Adam Smith Problem in Reverse: Self-Interest in The Wealth of Nations and The Theory of Moral Sentiments." History of Political Economy 40 (2): 365-382.

Paganelli, Maria Pia. 2009. “Approbation and the Desire to Better One's Condition in Adam Smith: When the Desire to Better One's Condition Does Not Better One's Condition and Society's Condition ..." Journal of the History of Economic Thought 31 (1): 79-92.

Paganelli, Maria Pia. 2010. "The Moralizing Role of Distance in Adam Smith: The Theory of Moral Sentiments as Possible Praise of Commerce." History of Political Economy 42 (3): 425-441.

Paganelli, Maria Pia. 2017a. "Boys Do Cry: Adam Smith on Wealth and Expressing Emotions." Journal of Scottish Philosophy 15 (1): 1-8.

Paganelli, Maria Pia. 2017b. "We Are Not the Center of the Universe: The Role of Astronomy in the Moral Defense of Commerce in Adam Smith." History of Political Economy 49 (3): 79-92.

Paganelli, Maria Pia. 2018. "Adam Smith on the Future of Experimental Evolution and Economics." Journal of Bioeconomics 20 (1): 23-28.

Paganelli, Maria Pia. Forthcoming. "Adam Smith and the Virtue of Punctuality." In The Scottish Enlightenment: The Science of Man, Social Theory, Moral Philosophy, edited by Robin Mills, and Craig Smith. Edinburgh: Edinburgh University Press. 
Sebastiani, Silvia. 2013. The Scottish Enlightenment: Race, Gender, and the Limits of Progress. New York, NY: Palgrave Macmillan.

Smith, Adam. (1759) 1981a. The Theory of Moral Sentiments. Edited by David D. Raphael, and Alexander L. Macfie. Vol. I of The Glasgow Edition of the Works and Correspondences of Adam Smith. Indianapolis, IN: Liberty Fund.

Smith, Adam. (1776) 1981b. An Inquiry into the Nature and Causes of the Wealth of Nations. Edited by Roy H. Campbell, and Andrew S. Skinner. Vol. II of The Glasgow Edition of the Works and Correspondence of Adam Smith. Indianapolis, IN: Liberty Fund.

Smith, Craig. 2006. Adam Smith's Political Philosophy: The Invisible Hand and Spontaneous Order. London: Routledge.

Storr, Virgil Henry, and Ginny Seung Choi. 2019. Do Markets Corrupt Our Morals? New York, NY: Palgrave Macmillan.

Maria Pia Paganelli is a Professor of Economics at Trinity University. She works on Adam Smith, David Hume, and $18^{\text {th }}$-century monetary theories. She wrote The Routledge Guidebook to Smith's "Wealth of Nations" (Routledge, 2020), and co-edited the Oxford Handbook of Adam Smith (Oxford University Press, 2013) and Adam Smith and Rousseau: Ethics, Politics, Economics (Edinburgh University Press, 2018). She served as the Vice President of the History of Economics Society and as the book review editor for the Journal of the History of Economic Thought. She is the current President of the International Adam Smith Society.

Contact e-mail: <mpaganel@trinity.edu> 